\title{
FINDING THE BRITISH GOOGLE: RELAXING THE PROHIBITION OF DUAL-CLASS STOCK FROM THE PREMIUM-TIER OF THE LONDON STOCK EXCHANGE
}

\author{
Bobby V. Reddy*
}

Key Words: Dual-Class Stock, Listing Rules, Long-Termism, One Share One Vote, Big Tech

Abstract

There is a dearth of British tech-companies listing on the London Stock Exchange (LSE), and the LSE lacks a large, innovative tech-company such as Google. The UK Government, concerned as to the loss of UK techcompanies to foreign acquirors, views the encouragement of UK tech-firm listings as a policy priority. Dualclass stock, currently prohibited from the LSE Main Market's premium-tier, allows founders to list their firms, and retain majority-control, while holding significantly less of the cash-flow rights in the company. This article will broach the potential for dual-class stock to attract UK tech-company listings, and extoll the benefits that dual-class stock can engender for UK tech-companies and their public shareholders. The risks of dual-class structures will also be discussed, but it will be shown that in a UK regulatory context, in relation to high-growth tech-companies, the risks may not be as severe as presumed, and easily moderated through judicious controls.

\section{INTRODUCTION}

The tech-industry loves an acronym. Google is a constituent of 'GAFA', a cabal of four US techcompany behemoths - Google, ${ }^{1}$ Apple, Facebook and Amazon. The Chinese equivalent is 'BATX' Baidu, Alibaba, Tencent and Xiaomi. These companies represent 'Big Tech'; a term referring to the current trend in major tech-companies with inordinate market, public and societal influence. ${ }^{2}$ As of

\footnotetext{
${ }^{*}$ Faculty of Law, University of Cambridge and Fellow of Churchill College, Cambridge. Former partner, Latham \& Watkins LLP. I thank the two anonymous referees for their insightful comments. Address for Correspondence: Churchill College, Cambridge CB3 0DS, UK. Email: bvr20@cam.ac.uk.

${ }^{1}$ On 2 October 2015, Alphabet, Inc. became the new listed holding company of Google. Throughout this article, the more common brand name, Google, will be used.

${ }^{2}$ R. Foroohar, "We need to talk about Big Tech" Financial Times (3 October 2017) $<$ https://www.ft.com/content/64a20c34a769-11e7-93c5-648314d2c72c > All URLs were last accessed on 1 November 2019 unless otherwise stated.
} 
October 2019, the total market capitalisation of the eight companies was nearly $\$ 4.4$ trillion, ${ }^{3}$ greater than the GDP of all but the largest three or four world economies. Perhaps more noteworthy is the manner in which such companies dominate the technology scene worldwide, consistently developing new technologies, software and hardware, and rampantly acquiring other innovative businesses. Furthermore, all of these companies are publicly-listed, giving them access to a source of equity capital for expansion and research and development (R\&D), as well as allowing public shareholders to participate in their success and growth. ${ }^{4}$

The UK Government has identified that innovation and investment in R\&D are critical to the future competitiveness and growth of the UK economy, ${ }^{5}$ and, to that end, has pinpointed attracting tech-firms to the London Stock Exchange (LSE) as a policy priority. ${ }^{6}$ However, the search for a 'British Google' has proved elusive. Although numerous UK 'unicorns', being private, independent start-ups valued at over $\$ 1$ billion, exist, ${ }^{7}$ only two tech-companies have been consistent members of the FTSE-100 since the dotcom bubble burst of the early 2000s. ${ }^{8}$ Those two companies, Micro Focus plc and Sage Group plc, listed in the 1980s, further highlighting the dearth of new, large techcompanies listing on the LSE.

Many factors could explain the reluctance of UK tech-company founders to list their companies, but one aspect is the fear of losing control of the company as a result of the shares becoming dispersed amongst public investors upon the company's initial public offering (IPO). Interestingly, six of the eight GAFA and BATX companies (and all of those that have listed in the twenty-first century) have utilised mechanisms that allow the founders to continue to control the composition of the board of directors and insulate the firm from takeovers (unless the founders

\footnotetext{
${ }^{3}$ Data sourced from Bloomberg stock quotes $<$ https://www.bloomberg.com/markets/stocks $>$

${ }^{4}$ See note 25 below.

${ }^{5}$ The Department for Business, Energy and Industrial Strategy’s Green Paper, "Building our Industrial Strategy" (January 2017), at 25 .

${ }^{6}$ See note 18 below.

${ }^{7}$ CBInsights, "The Global Unicorn Club: Private Companies Valued At $\$ 1 \mathrm{~B}+$ ” $<$ https://www.cbinsights.com/research$\underline{\text { unicorn-companies> }}$

8 N. Fildes, "Busy buyers leave only two UK tech giants standing" Financial Times (14 January 2018) $<\underline{\text { https://www.ft.com/content/39bc9b86-f464-11e7-88f7-5465a6ce1a00 }>}$
} 
consent) notwithstanding a dispersion of the equity upon IPO. The most common mechanism implemented is dual-class stock. ${ }^{9}$ The use of dual-class stock allows the founders to hold shares to which are attached enhanced voting rights, while the public shareholders own shares which enjoy lesser, or no, voting rights. A founder is therefore able to retain voting-control of the relevant company, while holding a minority of the equity. Google is a case-in-point - the founders, Larry Page and Sergey Brin, as of 31 December 2018, owned 51 per cent. of the voting rights of the company, but only 11.3 per cent. of the cash-flow rights. ${ }^{10}$ In the UK, on the most prestigious tier of the LSE's Main Market - the premium-tier - dual-class stock is prohibited, and the concept of oneshare-one-vote (OSOV) is effectively prescribed. A company with the capital structure of Google would not be admitted to a listing on the premium-tier.

Dual-class capitalisation has been described in the US as "the most important issue in corporate governance today", ${ }^{11}$ and, accordingly, the literature in the US is saturated with academic studies evaluating the merits of dual-class stock. However, surprisingly, very little academic discourse on dual-class stock has flowed in the UK, even though, at one time, dual-class firms were not rare on the LSE, with bastions of the city such as Marks \& Spencer, ITV, Whitbread, Shell, Burton Group, Ranks and House of Fraser adopting the structure. As far as this author is aware, this is the first article in the era of Big Tech that evaluates dual-class stock purely from a UK standpoint. The subject is especially topical, with the Financial Conduct Authority (FCA) ${ }^{12}$ and the UK Government ${ }^{13}$ recognising the potential for dual-class stock to support long-term company performance and investment in tech-companies. Even more recently, speculation has been rife that the UK Government is exploring the use of dual-class stock as a means to attract the listing of tech

\footnotetext{
${ }^{9}$ Google, Facebook, Baidu, Xiaomi, and Tencent all utilise dual-class stock.

${ }^{10}$ Stock ownership information gathered from Schedule 13G/A filings, Form 4 Statement of Changes in Beneficial Ownership filings, and Form 5 Annual Statement of Changes in Beneficial Ownership filings.

11 J. Coffee, "Dual Class Stock: The Shades of Sunset" CLS Blue Sky Blog (19 November 2018) $<\underline{\text { http://clsbluesky.law.columbia.edu/2018/11/19/dual-class-stock-the-shades-of-sunset/> }}$

${ }^{12}$ FCA Discussion Paper DP17/2, "Review of the Effectiveness of Primary Markets: The UK Primary Markets Landscape" (February 2017), at Chapter 4 and pp. 8 and 22.

${ }^{13}$ HM Treasury, "Financing growth in innovative firms: Consultation" (August 2017), at 33.
} 
start-ups on the LSE. ${ }^{14}$ A normative assessment of dual-class stock from a UK perspective is long overdue.

In this article, a normative argument shall be made to liberalise the rules on dual-class stock for the benefit of the UK tech-industry specifically. A detailed study of empirical research will form the subject-matter of further study. In the first section of this article, the dearth of UK tech-company listings on the LSE will be discussed. The next section will outline the journeys taken by UK techcompanies as alternatives to listing. The third section will discuss the potential for dual-class structure to promote listings. The final sections of this article will balance the benefits that dual-class structure can bring to the success of high-growth tech-companies, with the potential risks to public shareholders. However, it will be argued that the UK's regulatory and market environment mitigates against the most extreme risks, and a relaxation of the premium-tier prohibition of dual-class stock could give the UK's tech-industry the boost that it needs.

\section{THE SHORTAGE OF HIGH-GROWTH TECH-COMPANIES ON THE LSE}

The UK has been, and continues to be, a hotbed for science and technology companies. As of mid2019, the UK was home to seventeen tech unicorns. ${ }^{15}$ However, the emergence of large, privatelyowned tech-companies has not been reflected in the publicly-listed sphere. UK technology IPOs on the LSE have lagged behind the US, with firms from 'new economy' ${ }^{16}$ industries listing on the LSE between 2007 and 2017 making-up only 14 per cent. of total market capitalisation, compared with 60 per cent. and 47 per cent. on NASDAQ and the New York Stock Exchange (NYSE), respectively. ${ }^{17}$

\footnotetext{
${ }^{14}$ D. Thomas et al, "UK seeks change in listing rules to lure tech start-ups" Financial Times (5 November 2019) $<\underline{\text { https://www.ft.com/content/d4d2da5a-fee8-11e9-be59-e49b2a136b8d }>~}$

${ }^{15}$ A. Heathman, "London Tech Week: The unicorn companies at the centre of UK tech" Evening Standard (10 June 2019) $<$ https://www.standard.co.uk/tech/london-tech-week-uk-tech-unicorns-list-2019-a4163366.htmll>; see note 7 above, and accompanying text.

${ }^{16}$ The 'new economy' has been variously defined, but generally references the economic structure resulting from the intersection of globalisation and information technology (M. Pohjola, "The New Economy: facts, impacts and policies" (2002) 14 Information Econ. \& Policy 133, at 134).

${ }^{17}$ HKEX Concept Paper, "New Board" (June 2017), at 11.
} 
Attracting tech-firms to the LSE is a policy objective in the $\mathrm{UK},{ }^{18}$ for two main reasons. Firstly, although an in-depth study of the benefits of burgeoning equity markets is beyond the scope of this paper, equity can provide a vital source of financing for tech-companies. For instance, innovative tech-companies with long product-cycles may struggle to procure debt funding without a robust profits history. In 2016, 68 per cent. of US IPOs involved pre-profit companies, rising to 75 per cent. and 92 per cent. of technology and biotechnology listings, respectively, ${ }^{19}$ perhaps as a result of those companies lacking access to debt funding. Also, tech-companies seeking finance for longterm, uncertain projects may be shunned by the debt markets. ${ }^{20}$ As such, it has been found that R\&D spending can be throttled without access to the equity markets. ${ }^{21}$ External equity investment becomes essential for those pre-profit firms seeking to commercialise R\&D. ${ }^{22}$ As a source of financing for tech-companies, an LSE-listing could encourage innovation, productivity and growth in the economy generally. ${ }^{23}$ Job creation will also be promoted, and the tech-sector will be one of the largest providers of employment moving forward. ${ }^{24}$ Second, UK individuals, or retail investors, can participate in the growth and success of tech-companies if they are listed. ${ }^{25}$ In contrast, subject to exceptions, ${ }^{26}$ private companies are not able to easily offer securities to the general public. ${ }^{27}$ Although individuals could garner indirect exposure to such companies through their investments in

\footnotetext{
${ }^{18}$ See note 5 above, at p. 67 ; note 12 above, at Chapter 4 ; note 13 above, at p. 33 ).

${ }^{19}$ HKEX Concept Paper (2017) (note 17 above, at p. 15).

${ }^{20}$ M. Maher and T. Andersson, "Corporate Governance: Effects on Firm Performance and Economic Growth" (1999) Organisation for Economic Co-Operation and Development 1, at 36.
}

${ }^{21}$ K. Gugler (ed.), Corporate Governance and Economic Performance (Oxford 2001), 29; M. Bradley et al, "On the Existence of an Optimal Capital Structure: Theory and Evidence" (1984) 39 J. Financ. Econ. 857, at 874.

${ }^{22}$ See note 13 above, at p. 9 .

${ }^{23}$ D. Cipollone, "Risky Business: A Review of Dual Class Share Structures in Canada and a Proposal for Reform” (2012) 21

Dalhousie J. Legal Stud. 62, at 69; K-H. Bae and J. Kang, "Does the Stock Market Benefit the Economy?” (2017) EFMA Symposium: Finance and Real Economy Accepted Papers (March 2017).

${ }^{24}$ UK Tech on the Global Stage: Tech Nation Report 2019 (2019) <https://technation.io/report2019/>

${ }^{25}$ S. Feldman, "BNA Insights: IPOs in 2016 Increasingly Include Dual-Class Shareholder Voting Rights” (2016) S.R.L.R. 1, at 3 .

${ }^{26}$ See e.g. FSMA 2000 (Financial Promotion) Order 2005, SI 2000/1529 as amended (FPO), articles 48 and 50.

${ }^{27}$ Companies Act 2006 (CA 2006), s. 755; Financial Services and Markets Act 2000 (FSMA 2000), Part II. 
pension plans, insurance products and investment funds, those institutional investors will desire to allocate significant funds to more liquid publicly listed investments. Furthermore, although such institutional investors can invest in tech-companies listed on other exchanges (and will actively seek global diversification), a significant proportion of investments by UK funds remains in the UK, ${ }^{28}$ and, therefore, policy-makers are seeking methods to promote the listing of UK tech-companies on the LSE specifically.

\section{WHAT'S HAPPENING TO UK TECH-COMPANIES?}

If UK tech-companies are not listing on the LSE, it begs the question as to what happens to them? It is possible that UK tech-companies are able to generate the equity-financing that they require without having to resort to the public markets. The distinction between venture capital (VC) and private equity is beginning to blur, with large funds, such as Softbank, making huge VC investments in techcompanies, ${ }^{29}$ and traditional private equity houses eschewing their usual buy-out strategies in favour of minority investments. ${ }^{30}$ However, even though late-stage VC funding has recently increased in the UK, which dominates the European market, it generally lags well behind the levels observed in the US. $^{31}$ Accordingly, in the UK, many tech-companies soon attain a size that is beyond further VC funding, ${ }^{32}$ and the FCA has identified a gap in available financing in the 'scale-up' phase during

\footnotetext{
${ }^{28}$ Office for National Statistics (ONS), "MQ5: Investment by insurance companies, pension funds and trusts: October to December 2018" (March 2019), at 26.

${ }^{29}$ S. Ghosh and P. Leskin, "SoftBank is reportedly taking control of WeWork. Here's a running list of all the Japanese giant's major investments in tech” Business Insider (22 October 2019) <https://www.businessinsider.com/running-list-softbankinvestments-2017-7?r=US\&IR=T>

${ }^{30}$ A. Schneider and C. Henrik, Boston Consulting Group, "Private Equity Minority Investments: Can Less Be More" (2 April 2015) <https://www.bcg.com/en-gb/publications/2015/private-equity-minority-investments-can-less-be-more.aspx $>$

${ }^{31}$ KPMG Enterprise, "Venture Pulse Q2 2018: Global analysis of venture funding" (July 2018), at 2, 43 and 74; note 12 above, at p. 26; note 13 above, at p. 14.

${ }^{32}$ S. Rigos, "The UK equity gap, 'Why is there no Facebook or Google in the UK?'” (2011) Greater London Authority, at 25.
} 
which technology start-ups seek to emerge as large, established businesses. ${ }^{33}$ Although, as above, the UK is home to a number of private company 'unicorns', it has been suggested that the UK, in fact, underperforms in their creation, and significantly trails the US and China. ${ }^{34}$

Even for those UK tech-companies that do survive and become established businesses, it seems that the creation of enduring unicorns is the exception rather than the rule. As shown in Table 1 appended, in the last five years, numerous large UK tech-companies, two of which were unicorns and the others were well on their way to becoming unicorns, have been acquired by foreign purchasers. UK tech-companies are disproportionately the subject of mergers and acquisitions (M\&A) activity compared with their international peers. ${ }^{35}$

Therefore, only a handful of UK tech-companies are developing into large, mature businesses, and a great number that do are being bought-out by foreign competitors or investment funds. This is concerning from a policy perspective, since UK investors will not be able to share in the success of those firms that are bought-out, and, although such acquisitions may not be associated with the wholesale movement of business abroad, they could see a drip-feed of jobs, talent and operations to the foreign jurisdiction. Just as concerning is that, as shown in Table 2 appended, many of those large UK tech-firms that do eventually list in the UK are also subsequently bought-out by foreign acquirors. Either way, it does not appear that the UK public equity markets are providing a stable, long-term home for UK tech-companies.

\section{LOSS OF CONTROL AS A FACTOR IN ESCHEWING FLOTATIONS}

If the UK regulators aspire to encourage more UK tech-firms to list on the LSE, a reasonable starting point is to question why such companies are disproportionately susceptible to foreign buy-outs

\footnotetext{
${ }^{33}$ See note 12 above, at p. 26 - 'scale-up companies' are those with average growth in employees or turnover of more than $20 \%$ per annum over three years, with a minimum of 20 employees at the start. Also, see note 13 above, at p.11; A. BravoBiosca, "Firm Growth Dynamics across countries" (2016) NESTA working paper no. 16/03 $<$ https://media.nesta.org.uk/documents/wp16-03 firm growth dynamics-17.pdf $>$

${ }^{34}$ See note 13 above, at p. 12.

${ }^{35}$ See note 12 above, at p. 26.
} 
compared to their US brethren. The answer may lie in examining the consequences of listing in the UK.

The Main Market of the LSE is split into two tiers, and, since 2010, those tiers have been labelled the premium-tier, to which greater corporate governance standards are ascribed, and the, lower, standard-tier. ${ }^{36}$ After the naming re-designation, non-voting shares were omitted from the premium-tier. In 2014, in response to a number of high-profile abuses by controlling shareholders, ${ }^{37}$ the Listing Rules sourcebook as published by the FCA exercising its primary market functions (the Listing Rules) were further amended, introducing two new 'Premium Listing Principles' to which premium-listed companies would be required to adhere. Essentially the new principles prescribed pure-OSOV on the premium-tier by requiring (i) all equity shares in a class to carry an equal number of votes, ${ }^{38}$ and (ii) the aggregate voting rights of each class of premium-listed shares to be broadly proportionate to the relative equity interests of each class in the company. ${ }^{39}$ In effect, other than inferior-voting preference shares where the shareholders are compensated for a lack of voting rights with enhanced dividend or distribution rights, ${ }^{40}$ the FCA formally proscribed the premium-listing of classes of shares where the voting rights attached to such shares are disproportionate to their cashflow rights. From a strict reading of the Premium Listing Principles, a structure where the enhancedvoting shares (superior-shares) are unlisted, and the inferior-voting shares (inferior-shares) are premium-listed would not be prohibited. However, where, under the Listing Rules, matters pertaining to premium-listed companies are required to be decided by shareholder-vote, those matters must be approved by a resolution of the holders of shares that have been admitted to a premium-listing. ${ }^{41}$ For those matters, the control to which the superior-shareholders aspire will be undermined. In any case, notwithstanding the wording of the Premium Listing Principles, it is unlikely that the FCA would

\footnotetext{
${ }^{36}$ Financial Services Authority, "Listing Regime Review: Feedback on CP09/24 and CP09/28 with final rules" (February 2010).

${ }^{37}$ B. Reddy, "The Fat Controller: Slimming Down the Excesses of Controlling Shareholders in UK Listed Companies" (2018) 38 O.J.L.S. 733, at 743 and 757-760.

${ }^{38}$ Listing Rules, Premium Listing Principle 3.

${ }^{39}$ Listing Rules, Premium Listing Principle 4.

${ }^{40}$ Non-voting preference shares are potentially permitted under Listing Rule (LR) 7.2.4G.

${ }^{41}$ LR 9.2.21R.
} 
admit a firm's inferior-shares to the premium-tier where the superior-shares are unlisted, since this would deviate from the spirit of the relevant Premium Listing Principles, the purpose of which is to 'prevent artificial structures involving multiple classes with different voting powers, which are designed to allow control to rest with a small group of shareholders' ${ }^{42}$ Even prior to the division of the Main Market into two tiers, and the introduction of the 2014 Premium-Listing Principles, since the 1960s, in response to pressure from powerful institutional investors, the LSE had discouraged the quotation of inferior-shares, and indicated that it would use its discretionary powers to refuse applications to list inferior-shares on its market in the majority of cases. ${ }^{43}$ A combination of the LSE's informal prohibition and institutional investor distaste for dual-class stock (increasing the cost of equity-capital for dual-class companies) led to most UK-listed dual-class firms unifying their share structures into OSOV well before the formal premium-tier prohibition of dual-class stock was implemented. ${ }^{44}$

A OSOV-listing on the premium-tier could create complications for a founder. Upon IPO, as the founder sells-down its equity, or dilutes its equity through the issuance of further shares, the founder will see the proportion of its voting rights in the company decline. If the founder's share of the voting rights falls below a majority, for a company incorporated in England and Wales, the founder will no longer possess the ability to determine the composition of the board of directors. ${ }^{45}$ Since, generally, the power to appoint the company's management team will reside with the board, ${ }^{46}$ the loss of majority-control exposes management. If the founder is part of the management team, the founder loses its protected position and could, therefore, be indirectly dismissed from running the

\footnotetext{
${ }^{42}$ FCA Policy Statement PS14/8, "Response to CP13/15 - Enhancing the effectiveness of the Listing Regime" (May 2014), at 31 .

${ }^{43}$ B. Cheffins (ed.), Corporate Ownership and Control: British Business Transformed (Oxford 2008), 317 and 32; B. Cheffins (ed.), Company Law: Theory, Structure and Operation (Oxford 1997), 472 and 475.

${ }^{44}$ Cheffins (2008) (ibid., at pp. 309 and 317); J. Franks and C. Mayer, "Evolution of Ownership and Control Around the World: The Changing Face of Capitalism” (2017) ECGI Finance Working Paper No. 503/2017 1, at 13.

${ }^{45}$ See CA 2006, s. 168, and Companies (Model Articles) Regulations 2008, SI 2008/3229 (the Model PLC Articles), article 20. In the absence of bespoke articles of association, the Model PLC Articles will apply (CA 2006, s. 20), and, commonly, public companies adopt an amended version of the Model PLC Articles.

${ }^{46}$ Model PLC Articles, article 3.
} 
company by shareholders holding a majority of the votes. The firm, and, therefore, management, also becomes exposed to a third-party takeover which the founder can no longer block.

A founder could list on the premium-tier and retain voting-control, resulting in a 'OSOVcontrolling shareholder firm', thereby maintaining its protected position in leading the company. However, this entails other compromises. In order to retain more than fifty per cent. of the voting rights, the founder will have to limit both the crystallisation of his/her investment in the company through the sale of shares, and the generation of equity funding for company growth through issuing shares. The founder either lists and loses control, or lists and retains control but forsakes the very reasons for listing in the first place. Milo Minderbinder would struggle to formulate such a clear-cut 'catch-22'. ${ }^{47}$

Almost as a deus ex machina, the catch-22 scenario could be solved if the adoption of dualclass stock were permitted on the premium-tier. A founder could retain superior-shares, while issuing inferior-shares to the public, thereby maintaining control of the company by holding a majority of the voting rights, while still crystallising significant wealth by selling equity in the company. Issuances of further equity, either at IPO or subsequently, can also be engineered through the sale of newlycreated inferior-shares, thereby limiting the dilution of the founder's voting rights. In addition, once listed, a founder holding superior-shares can block takeovers, negating concerns that a flotation could result in the firm subsequently being acquired and the founder removed from running the firm. Dualclass stock would, therefore, also attenuate the loss of listed tech-firms from the Main Market.

It should be noted that dual-class stock is only prohibited from the premium-tier. As a matter of corporate law, companies have complete freedom to adopt dual-class structures, ${ }^{48}$ and even in the listed-company sphere, dual-class stock listings are permitted on the Alternative Investment Market (AIM) and the Main Market's standard-tier. However, AIM was established for smaller, growing companies, ${ }^{49}$ with less onerous listing requirements, and therefore embraces an investor-base reflective of the types of companies that list on the exchange. For a unicorn, a growing mid-stage tech-company with high funding requirements, or, indeed, the British Google, it is unlikely that AIM

\footnotetext{
${ }^{47}$ Catch-22 by J. Heller (New York 1961); also see N. Wasserman, “The Founder Dilemma” (2008) 86 H.B.R. 102.

${ }^{48}$ Bushell v Faith [1970] AC 1099.

${ }^{49}$ White Page Ltd in association with the London Stock Exchange, "A Guide to AIM” (2010), at 4.
} 
would represent a suitable market to promote the levels of liquidity or raise the levels of finance required.

With respect to the standard-tier, an inferiority-complex pervades. More stringent admission requirements apply to the premium-tier, lending it greater prestige. The stronger corporate governance qualities ascribed to the premium-tier beget greater confidence in the market, attracting superior levels of investment by a larger number of sophisticated investors. As a result, issuers are themselves attracted to the premium-tier where they can draw greater levels of investment at, potentially, a better price than compared to the standard-tier. Advisors often caution clients against choosing the standard-tier for listing. ${ }^{50}$ Even the FCA has admitted that a standard-listing is often considered unattractive for many potential issuers, with the very name connoting 'second-best' status. ${ }^{51}$ One may question whether the 'unattractiveness' of the standard-tier could be overcome by the 'attractiveness' of a high-quality dual-class share issuer. After all, a sophisticated institutional investor is unlikely to shoot-itself-in-the-foot and pass-up a 'hot' IPO merely due to the second-rate perception attached to the 'standard-tier' moniker. However, many of the key continuing corporate governance requirements attached to a premium-, but not standard-, listing are exactly the types of protections that an institutional investor would regard as essential prior to investing in dual-class shares in the UK. For example, premium-tier companies are subject to regulations surrounding related-party transactions, ${ }^{52}$ and controlling shareholders of such companies must contractually restrict certain of their actions. ${ }^{53}$ The lower corporate governance standards of a standard-listed company would most likely be even more of a deterrent to investors where the company is issuing dual-class shares. The relevant issuer could voluntarily adopt equivalent protections, but such protections would not be subject to regulatory oversight, and therefore likely to be contractual or implemented through the constitutional documents of the issuer. Investors would be required to

\footnotetext{
${ }^{50}$ See note 12 above, at p. 19.

${ }^{51}$ Ibid., at p. 19.

${ }^{52}$ See note 126 below, and accompanying text. In the US, investors can also take some comfort from constraints on relatedparty transactions (see note 134 below).

${ }^{53}$ Controlling shareholders must enter into 'relationship agreements' with their companies (see note 131 below, and accompanying text).
} 
examine and analyse the relevant contractual and constitutional provisions themselves to ensure equivalence to premium-tier regulatory requirements - the appetite of investors to make such determinations on a case-by-case basis can be doubted, and it has been suggested that the ability of investors to accurately assess more granular elements of a company's bespoke corporate governance qualities is limited..$^{54}$

A founder could be further discouraged from a standard-listing since such firms are excluded from the UK FTSE-indices. Certain funds passively track the indices, slavishly only investing in index constituents on a weighted-basis, ${ }^{55}$ and even some active funds could be considered 'closetindexers ${ }^{, 56}$ in that they are either mandated to only invest in specific indices, or they track an index as a hedging strategy where the performance of the relevant fund manager is assessed against the index. ${ }^{57}$ As a consequence of such demand, index-inclusion can be associated with greater liquidity and higher share prices. ${ }^{58}$ If a standard-tier firm were to grow to a size that would otherwise be worthy of index-inclusion, it would not be able to take advantage of the associated benefits. Pertinently, excluding preference shares, there has not been a dual-class share IPO on the standard-tier since the re-designation of the Main Market into premium- and standard-tiers, and the exclusion of non-voting stock from the premium-tier in 2010. Although, three companies, Schroders plc (Schroders), Hansa Investment Company Limited (Hansa), and Daily Mail \& General Trust plc (Daily Mail), do have inferior-shares listed on the standard-tier, ${ }^{59}$ all three were long-time members of the

\footnotetext{
${ }^{54}$ Bebchuk, "Asymmetric Information and the Choice of Corporate Governance Arrangements" (2002) Harvard Law School Discussion Paper No. 398 1; L. Bebchuk and K. Kastiel, “The Untenable Case for Perpetual Dual-Class Stock” (2017) 4 Va. Law Rev. 585, at 623 .

${ }^{55}$ L. Bebchuk and S. Hirst, "Index Funds and the Future of Corporate Governance: Theory, Evidence, and Policy" (November 2018) 1, at $15<$ https://papers.ssrn.com/sol3/papers.cfm?abstract id=3282794>

${ }^{56}$ S. Hirst and K. Kastiel, “Corporate Governance by Index Exclusion” (2019) 99 B.U.L.R. 1229, at 1250.

${ }^{57}$ B. Cheffins, "The Undermining of UK Corporate Governance (?)" (2013) 33 O.J.L.S. 503, at 513; Hirst and Kastiel (2019) (ibid., at p. 1256).

${ }^{58}$ B. Sharfman, “A Private Ordering Defense of a Company's Right to Use Dual Class Share Structures in IPOs” (2018) 63 Villanova Law Rev. 1, at 4; D. Lund, "Nonvoting Shares and Efficient Corporate Governance" (2019) 71 Stanf. Law Rev. 687, at p. 711; Hirst and Kastiel (2019) (ibid., at pp. 1253-1254).

${ }^{59}$ FCA's “The Official List” as of 25 November 2019.
} 
Main Market's former 'primary-tier' and found their inferior-shares downgraded to the standard-tier upon the prohibition of non-voting stock from the premium-tier becoming effective. The superiorshares of Schroders and Hansa continue to be premium-listed, and those of Daily Mail were never listed. The companies' inferior-shares are subject to standard-listings not through choice, but as a result of regulatory exigencies. Given the rise in recent years of large tech-firms listing in the US with dual-class structure, ${ }^{60}$ the rarity of firms taking advantage of dual-class stock on the standard-tier is indicative of the low regard in which the segment is held by issuers.

A UK tech-firm could also adopt dual-class structure by listing on a foreign exchange such as NASDQ or the NYSE. However, in such a case, the foreign exchange and foreign-based advisors will extract the majority of the financial benefits accruing to the listing, which would presumably undermine some of the FCA's policy objectives. Additionally, as described above, a foreign listing would make it more difficult for UK-based retail investors to share in the growth of the relevant company. ${ }^{61}$ In any case, it does not appear that UK tech-firms are racing toward the US exchanges. ${ }^{62}$ A number of factors could explain the reticence, including the fact that the success of the listing may be hindered by an unfamiliarity in the foreign market with the brand and products of the UK company, and the firm will also not be able to leverage the publicity of the listing into better sales in

\footnotetext{
${ }^{60}$ Taking IPOs on NYSE America, NASDAQ and the NYSE with offer prices of at least $\$ 5.00$, the proportion of techcompany IPOs adopting dual-class structure rose from 4.9 per cent. in 2004, the year of Google's IPO, to 34.2 per cent. in 2018 (J. Ritter, "Initial Public Offerings: Dual Class IPOs" (updated as of 19 December 2018) $<$ https://site.warrington.ufl.edu/ritter/files/2019/04/IPOs2018DualClass.pdf $>$ ).

${ }^{61}$ See note 28 above, and accompanying text. Additionally, if UK retail investors desire to invest in foreign listed companies directly (rather than indirectly through institutional funds) it will involve foreign-based investment accounts and unfamiliar regulations.

${ }^{62}$ As of 31 October 2019, only three UK tech-companies had stock listed exclusively on the NYSE - Farfetch Ltd. (Farfetch), International Game Technology plc, and Delphi Technologies plc (NYSE, "Current List of All Non-U.S. Issuers" $(2019)<$ https://www.nyse.com/publicdocs/nyse/data/CurListofallStocks.pdf $>$ ). Farfetch adopted a dual-class stock structure at IPO. From a search of NASDAQ's “company list” as of 25 November 2019

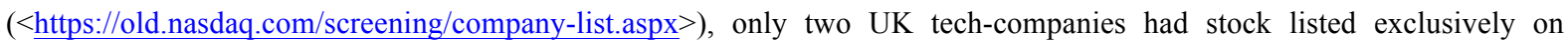
NASDAQ - Mimecast Ltd. and IHS Markit Ltd.
} 
its main product-market. ${ }^{63}$ Higher listing costs, with requirements to instruct foreign as well as local advisors and to ensure that accounts are compatible with the foreign jurisdiction's requirements, may also deter foreign listings, ${ }^{64}$ as may a fear of an unfamiliar litigious culture in the foreign jurisdiction. ${ }^{65}$ The provenance of the pre-IPO investors can also influence the listing jurisdiction, with a bias toward UK listings by UK-based investors. ${ }^{66}$

In summary, there could be many reasons why a particular UK tech-company eschews a flotation of its stock, including a distaste for increased regulatory oversight and transparency, but the catch-22 described above will play heavily on the mind of the founder. Control is key. A founder will lose control upon a OSOV-listing if it desires to substantially diversify wealth and grow the firm. Even in circumstances where a founder sells its private company to a third-party, if the acquiror shares a similar vision to the founder, and has a track-record for giving businesses the space to grow long-term, the founder may be content to cede voting-control to the acquiror in return for a high purchase price, the award of a non-trivial stake in the acquiror, and a degree of autonomy in running the business going forward. The attractions in betting on a known quantity are obvious compared to being exposed to a disparate, ever-changing group of public shareholders. Dual-class stock, on the other hand, enables founders to pursue the benefits of a listing while retaining control, evidenced by the rising numbers of such listings in the US. ${ }^{67}$

\footnotetext{
${ }^{63}$ M. Pagano et al, “The Geography of Equity Listing: Why Do Companies List Abroad?" (2002) 57 J. Financ. 2651, at 2658-9.

${ }^{64}$ J. Fanto and R. Karmel, "A Report on the Attitudes of Foreign Companies Regarding a U.S. Listing” (1997) 3 S.J.L.B.F.

51 , at 66 .

${ }^{65}$ Ibid., at p. 67.

${ }^{66}$ C. Silva, "Why the LSE can serve tech startups better than Nasdaq or the NYSE" Guardian (10 November 2016)

$<$ https://www.theguardian.com/business/blog/2016/nov/10/lse-tech-startups-nasdaq-nyse-investors $>$

${ }^{67}$ See note 60 above.
} 


\section{HOW DUAL-CLASS SHARE STRUCTURE COULD BENEFIT UK \\ TECH-FIRMS}

The lure of dual-class stock does not solely lie in its potential to encourage the listing of tech-firms on the LSE. The adoption of the structure by an issuer can also engender separate benefits for the firm itself and its public shareholders. In this section, the benefits of dual-class stock from the perspective of tech-companies will be elucidated. It is assumed for the purposes of this article that a controller or controllers will hold a majority of the voting-rights in the relevant dual-class company. Taking the US as an example, if dual-class firms became common on the premium-tier, the prospect for numerous dispersed-ownership dual-class firms would be vanishingly small. ${ }^{68}$

At IPO, the founders of Google stated, "we have set up a corporate structure that will make it harder for outside parties to take over or influence Google. This structure will also make it easier for our management team to follow the long term, innovative approach emphasized earlier". ${ }^{69}$ The enabling of taking a long-term approach to business has been oft-cited by academics and regulators alike as a benefit attached to the adoption of dual-class stock. ${ }^{70}$ With control in the hands of the superior-shareholders, assuming that the superior-shareholders themselves have a long-term outlook, the management team can operate the business without fear that they may be removed if short-term metrics are not positive. ${ }^{71}$ Furthermore, the market for corporate control, ${ }^{72}$ pursuant to which

\footnotetext{
${ }^{68}$ L. Bebchuk and K. Kastiel, "The Perils of Small-Minority Controllers" (2019) 107 Geo. L.J. 1453, at 1496 found that $83.6 \%$ of Russell-3000 dual-class companies have a controlling minority shareholder (an earlier draft noted the figure as $96.7 \%$ of S\&P-1500 dual-class firms).

${ }^{69}$ Google Inc. Amendment No. 8 to Registration Statement (filed on 16 August 2004), at 29.

${ }^{70}$ See e.g. D. Fischel, “Organized Exchanges and the Regulation of Dual Class Common Stock” (1987) 54 U. Cm. L. Rev. 119, at 139; H. DeAngelo and L. DeAngelo, "Managerial Ownership of Voting Rights, A Study of Public Corporations with Dual Classes of Common Stock" (1985) 14 J. Financ. Econ. 33, at 35; G. Dent, "Dual Class Capitalization: A Reply to Professor Seligman" (1987) 54 Geo. Wash. L. Rev. 725, at 764; A. Choi, "Concentrated Ownership and Long-Term Shareholder Value" (2018) 8 H.B.L.R. 53, at 59; Z. Goshen and A. Hamdani, "Corporate Control and Idiosyncratic Vision" (2016) 125 Yale L.J. 560; SGX, “Consultation Paper on Possible Listing Framework for Dual Class Share Structures” (16 February 2017) 1, at 9; HKEX, “Concept Paper: Weighted Voting Rights” (August 2014) 1, at 23.

${ }^{71}$ M. Narayanan, “Managerial Incentives for Short-Term Results” (1985) 40 J. Finance 1469, at 1479.
} 
moribund short-term share price can lead to predatory takeover offers by third-party acquirors, is largely eroded, since a takeover can only proceed with the consent of the superior-shareholders. In contrast, with a robust market for corporate control, management will be at the behest of those shareholders who may make misjudgments in accepting predatory takeover offers that are not in the best interests of those shareholders or the firm, ${ }^{73}$ which can cause management to be overly preoccupied with short-term share price in priority to the long-term interests of the company. ${ }^{74}$ Whether public shareholders are in fact overall short-term orientated is beyond the scope of this article, but studies have shown that even the mere perception that the markets are short-termist can influence the behaviour of management, ${ }^{75}$ and those shareholders with short-term proclivities can have a disproportionate impact on managerial behaviour due to the high turnover of stock generated by their activities. ${ }^{76}$ With dual-class stock, management will be less likely to invest in projects with observable payoffs that will produce lower returns than projects that are more challenging to monitor, or to employ costly signalling devices such as dividend payments, share buy-backs, or leverage to inform outsiders that performance is robust where it is otherwise difficult to monitor. ${ }^{77}$

The ability to take a long-term approach can particularly benefit tech-companies. They are often involved in product innovation, and, especially in their early, growth-phase years, seek success through the exploitation of product-cycles, which can increase R\&D investment at the expense of

\footnotetext{
${ }^{72}$ For a description of the market for corporate control, see the seminal work by Henry Manne: H. Manne, "Mergers and the Market for Corporate Control” (1965) 73 J. Political Econ. 110.

${ }^{73}$ Lund (2019) (note 58 above, at p. 687); Z. Goshen and R. Squire, "Principal Costs: A Theory for Corporate Law and Governance" (2017) 117 Colum. L. Rev. 767, at 784; J. Gordon, “Ties that Bond: Dual Class Common Stock and the Problem of Shareholder Choice" (1988) 76 Cal. L. Rev. 1, at 44.

${ }^{74}$ J. Stein, “Takeover Threats and Managerial Myopia” (1988) 96 J. Political Econ. 61.

${ }^{75}$ M. Moore and E. Walker-Arnott, “A Fresh Look at Stock Market Short-termism” (2014) 41 J. Law Soc. 416, at 430 and 438); A. Brandenburger and B. Polak, "When managers cover their posteriors: making the decisions the market wants to see” (1996) 27 RAND J. Econ. 523; N. Mizik, “The Theory and Practice of Myopic Management” (2010) 47 J. Mark. Res. 594 , at 594 .

${ }^{76}$ The Kay Review of UK Equity Markets and Long-Term Decision Making: Final Report (July 2012), at 38.

${ }^{77}$ K. Lehn et al, "Consolidating corporate control: Dual-class recapitalizations versus leveraged buyouts" (1990) 27 J. Financ. Econ. 557, at 564; Fischel (1987) (note 70 above, at p. 138); A. Alchian and H. Demsetz, "Production, Information Costs, and Economic Organization” (1972) 62 Am. Econ. Rev. 777, at 789.
} 
short-term profits. ${ }^{78}$ If founders are under pressure from equity market investors to maintain strong short-term profits and distributions, the ability of the founder to pursue such product-cycles will be diminished. ${ }^{79}$ For example, where a firm has a choice between projects with high or low near-term uncertainty, even if the project with high near-term uncertainty will be more profitable in the longterm, with a OSOV dispersed-ownership firm, management may be more likely to pursue the less profitable project. Outside shareholders take longer to determine the possible success of projects with high near-term uncertainty, valuing such products less highly, all things being equal, and, as such, management requires insulation from removal, while share price may be undervalued, in order to pursue the more valuable project. ${ }^{80}$ The scenario is likely to occur in industries requiring high R\&D investment, and, therefore, those industries can benefit from the utilisation of dual-class stock. ${ }^{81}$

Innovative tech-firms, such a Google and Facebook, also require the investment of firmspecific capital by management and employees. Managers will be more likely to invest in firmspecific human capital, if they are comfortable that their positions are secure in the long-term. ${ }^{82}$ The long-term commitment of the controller can also encourage other employees to invest in the firm-

\footnotetext{
${ }^{78}$ S. Kupor, "Sorry CalPERS, Dual Class Shares Are A Founder's Best Friend" Forbes CIO Network (14 May 2013) $<$ https://www.forbes.com/sites/ciocentral/2013/05/14/sorry-calpers-dual-class-shares-are-a-founders-best-
} friend/\#5e896b6412d9>

${ }^{79}$ Google's founders, in justifying its capital structure, stated: “Technology products often require significant investment over many years to fulfill their potential. For example, it took over three years just to ship our first Android handset, and then another three years on top of that before the operating system truly reached critical mass. These kinds of investments are not for the faint-hearted. We have protected Google from outside pressures and the temptation to sacrifice future opportunities to meet short-term demands." (Alphabet's 2011 Founders' Letter (31 December 2011) $<\underline{\text { https://abc.xyz/investor/founders-letters/2011/>). }}$

${ }^{80}$ J. Chemmanur, "Dual Class IPOs: A theoretical analysis" (2012) 38 J. Bank. Finance 305, at 306.

${ }^{81}$ Ibid., at p. 315; Burkart et al, "Large Shareholders, Monitoring, and the Value of the Firm" (1997) Q.J. Econ. 693, at 718; Davies et al, "Measuring the Costs of Short-Termism” (2014) 12 J. Financ. Stab. 16, 18.

${ }^{82}$ D. Denis and D. Denis, "Majority owner-managers and organizational efficiency" (1994) 1 J. Corp. Finance 91, at 106; DeAngelo and DeAngelo (1985) (note 70 above, p .62); Fischel (1987) (note 70 above, at p. 137); S. Smart and C. Zutter, "Control as a motivation for underpricing: a comparison of dual and single-class IPOs" (2003) 69 J. Financ. Econ. 85, at p. 103; E. Böhmer et al, "The Effect of Consolidated Control on Firm Performance: The Case of Dual-class IPOs" in M. Levis (ed.), Empirical Issues in Raising Equity Capital (Indiana 1996), 111. 
specific human capital so essential in companies with high asset-specificity such as high technology industries; the adoption of long-term projects by companies in such industries would give employees comfort that the company is committed to long-term relationships with those employees. ${ }^{83}$ For example, in justifying the company's dual-class structure, Google's founders, in their 2011 Founders' Letter to Investors, stated: "Our colleagues will be able to trust that they themselves and their labors of hard work, love and creativity will be well cared for by a company focused on stability and the long term." ${ }^{\prime 84}$ The long-term value of intangible assets and human resources may be misjudged by public shareholders, ${ }^{85}$ and commentators have speculated that innovation is promoted in companies where there is greater tolerance of short-term moribund share performance. ${ }^{86}$ Additionally, tech-companies often need to develop other important long-term stakeholder relationships, such as with vital customers, suppliers or partners. A reputation for a long-term approach, which is often associated with controlling shareholder companies,${ }^{87}$ may send a message to potential contracting parties that the company's management can be trusted since they can be assumed to have a desire to manufacture long-lasting contractual relationships; ${ }^{88}$ dual-class stock can promote such a reputation and therefore assist in ingraining long-term stakeholder relationships. ${ }^{89}$ Effectively, management insulation creates a permissive environment in which a tech-company can take a long-term view to its business.

${ }^{83}$ C. Mayer, "Corporate Governance, Competition, and Performance" (1997) 24 Corp. Gov. 152, at 168; note 20 above, at p. 28.

${ }^{84}$ Alphabet Founders' Letter (2011) (note 79 above).

${ }^{85}$ R. Gilson, "Controlling Shareholders and Corporate Governance: Complicating the Comparative Taxonomy" (2006) 119 Harv. Law Rev. 1642, at 1669.

${ }^{86}$ GUBERNA Position Paper, "Re-Designing Corporate Governance to Promote Innovation" (January, 2016), at 7; G. Manso, "Motivating Innovation” (2011) 66 J. Financ. 1823, at 1852.

${ }^{87}$ This is particularly true of family controlled companies - see: B. Cheffins, "Corporate Law and Ownership Structure: A Darwinian Link?” (2002) 25 U.N.S.W. L.J. 346, at 363. Also, see: Mayer (1997) (note 83 above, at p. 168); note 20 above, at p. 9 .

${ }^{88}$ R. Gilson, "Controlling Family Shareholders in Developing Countries: Anchoring Relational Exchange” (2007) 60 Stan. L. Rev. 633, at 643; Cheffins (2002) (ibid., at p. 363).

${ }^{89}$ In the context of takeover defences generally: Cremers et al, "Staggered boards and long-term, firm value, revisited" (2017) 126 J. Financ. Econ. 422, at 442; W. Johnson et al, “The Lifecycle Effects of Firm Takeover Defenses” (2018) 1, at $29<\underline{\text { http://dx.doi.org/10.2139/ssrn.2808208>; }}$ Mayer (1997) (note 83 above, at p. 168). 
The support of long-termism through management insulation is also a quality of OSOVcontrolling shareholder-structures, ${ }^{90}$ but, even so, if dual-class stock encourages the listing of companies with controllers that would not otherwise list with OSOV-structure (due to the compromises that must be made), ${ }^{91}$ the structure should be promoted. Furthermore, the propensity to take a long-term approach may be amplified with dual-class stock since the controller, if it holds a disproportionately small level of cash-flow rights, will be less concerned by any short-term personal changes in net-worth correlating with share price fluctuations. With OSOV, share price is apposite if the controlling shareholder intends to sell-down equity, but with dual-class stock, it is likely that the controller will already have disposed of a substantial proportion of its equity. Of course, if the market is indeed overall short-term orientated, inferior-share price may decline if short-term performance is poor, particularly if long-term value is not easily observable, but a diversified superior-shareholder controller will be able to stay the course, and those inferior-shareholders who are also long-term orientated and continue on the journey with the controller will be able to enjoy those long-term profits along with the controller.

Another benefit of dual-class stock for tech-companies, very much related to the concept of long-termism, is that it can support risk-taking. With OSOV dispersed-ownership firms, a regulatory prioritisation of robust monitoring (resulting in various mechanisms, such as independent directors, being implemented to substitute for a lack of scrutiny by dispersed-shareholders) has been accused of blunting innovation in favour of curtailing the excesses of unfettered management. ${ }^{92}$ Significantly, calculated risk-taking can be critical to the success of growth-phase tech-companies desiring to develop transformational and disruptive technologies. ${ }^{93}$ Two aspects of dual-class structure can encourage greater risk-taking and innovation, that could benefit all the shareholders in the company.

\footnotetext{
${ }^{90}$ See note 37 above, at p. 739.

${ }^{91}$ See note 47 above, and accompanying text.

${ }^{92}$ For example: S. Bianchini et al, "Corporate Governance, Innovation and Firm Age: Insights and New Evidence" (2015) GREDEG Working Papers Series 2015-05 1; GUBERNA (2016) (note 86 above); B. Reddy, "Thinking Outside the Box Eliminating the Perniciousness of Box-Ticking in the New Corporate Governance Code" (2019) 82 M.L.R. 692.

${ }^{93}$ B. Nagji and G. Tuff, "Managing Your Innovation Portfolio" H.B.R. (May 2012), at 9.
} 
Firstly, even though the corporate governance requirements that seemingly inhibit risk-taking will still apply to premium-listed dual-class firms, their impact on the controller's decision-making (and risk-taking) will be reduced where the management team is insulated. ${ }^{94}$ Although the lesser effectiveness in controlling shareholder firms generally of independent directors, ${ }^{95}$ and the UK Corporate Governance Code (UK CGC), ${ }^{96}$ can be viewed negatively in not constraining the acts of controllers, it can also be viewed positively by giving controllers greater freedom to take risks.

Second, dual-class structure can enhance risk-taking from the perspective of the economic incentives of the controller. In a OSOV dispersed-ownership firm, management will be cautious in gambling on a risky, although potentially highly profitable, project if their employment could be imperilled by the project resulting in failure. Even in a OSOV-controlling shareholder firm, where management is insulated from outside shareholders, management may still exercise caution, since a single large failure could result in a sizeable diminishment in wealth of the controller, to whom they owe their employment (or the controller itself will be part of management). ${ }^{97}$ This wealth consideration in fact seems to dominate over outside shareholder insulation, since OSOV-controlling shareholder firms have been shown to be more, rather than less, risk-averse than OSOV dispersedownership firms. ${ }^{98}$ In contrast, with dual-class stock where the founder has disposed of substantial equity, the managers are still insulated from public shareholders by the controller's voting-power, but are also less pre-disposed to considering the wealth-effects of individual decisions since they will

\footnotetext{
${ }^{94}$ Smart and Zutter (2003) (note 82 above, at p. 103).

${ }^{95}$ In the presence of a controlling shareholder, since, ultimately, the controller can determine the composition of the board, the true independence of the independent directors has been questioned (note 37 above, at p. 754).

${ }^{96}$ The UK CGC is premised on the concept of disclosure of corporate governance arrangements, giving outside shareholders the information they need to instigate change if desired. However, in the presence of a controlling shareholder, corporate governance measures will have been implemented at the behest, or at least with the tacit approval, of the controller.

${ }^{97}$ A. Edmans, "Blockholders and Corporate Governance" (2014) 6 Annu. Rev. Financ. Econ. 23, at 33; also see: Cheffins (2002) (note 87 above, at p. 357); C. Holderness, “A Survey of Blockholders and Corporate Control” (2003) FRBNY Econ. Policy Rev. 51, at 56; D. Ashton, “Revisiting Dual-Class Stock” (1994) 68 St. John's L. Rev. 863, at 927; R. Gilson and B. Black (eds.), The Law and Finance of Corporate Acquisitions (New York 1995), 784.

${ }^{98}$ M. Faccio et al, "Large Shareholder Diversification and Corporate Risk-Taking" (2011) 24 Rev. Financ. Stud. 3601, at 3621 (risk was measured by the volatility of profitability).
} 
affect the founder less than would have been the case if it had retained a proportionate level of cashflow rights. As such, so long as the single risk does not pose a seismic or terminal threat to the health of the company, by making many calculated risks over a long period of time, a talented founder can overcome the loss-aversion to individual gambles by assessing the possibility of more 'winners' than 'losers' over time. ${ }^{99}$ Hence, empirically, firms adopting dual-class stock, concurrently with the controller selling-down substantial equity, have been found to be associated with greater risk-taking which was beneficial to firm-wealth and all shareholders. ${ }^{100}$

Inferior-shareholders in dual-class firms can also garner significant benefits from a talented founder being 'bonded' to the firm. ${ }^{101}$ If the controller has already divested of the majority of its equity, it has more to lose than gain by selling its shares, since the controller will lose the pecuniary and non-pecuniary benefits that it accrues from being in control ${ }^{102}$ in return for only the price of a sliver of equity. ${ }^{103}$ The strength of the bond would be additionally reinforced in the UK, where takeover regulations could make the superior-shares somewhat illiquid - a possible purchaser of shares may be deterred from acquiring the superior-shares, since an acquisition of 30 per cent. or more of the voting rights would require the bidder to make an offer for all the shares in the company under the UK's mandatory bid rules. ${ }^{104}$ Accordingly, a purchaser not wishing to obtain control of the company (but wishing to acquire a significant equity stake) would be more likely to acquire inferiorshares and avoid triggering the mandatory bid requirement. Additionally, much in the same way as a reputation for taking a long-term approach can ingrain stakeholder relationships ${ }^{105}$ the attachment of

\footnotetext{
${ }^{99}$ By analogy, see the wager formulation in D. Kahneman (ed.), Thinking, Fast and Slow (New York 2011), 336.

${ }^{100} \mathrm{~S}$. Bauguess et al, "Shareholder diversification, corporate risk taking, and the benefits of changing to differential voting rights" (2012) 36 J. Bank Finance 1244, at 1251.

${ }^{101}$ Fischel (1987) (note 70 above, at p. 137); SGX Consultation Paper (2017) (note 70 above, at p. 9). Also, see note 106 above.

${ }^{102}$ See 'WHY PROHIBIT DUAL-CLASS STOCK FROM THE PREMIUM-TIER?' below

${ }^{103}$ Choi (2018) (note 70 above, at p. 68). This assumes the absence of a control premium, as would be the case in the UK (note 168 below, and accompanying text).

${ }^{104}$ The Takeover Code as published by the UK's Panel on Takeovers and Mergers (Takeover Code), Rule 9. Also, see note 168 below, and accompanying text.

${ }^{105}$ See notes 87-89 above, and accompanying text.
} 
a respected founder to a business can generate trust by, and signal quality to, customers and other stakeholders. ${ }^{106}$

In fact, the controller-bonding hypothesis could be a crucial benefit for inferior-shareholders in tech-firms where the vision of the founder is fundamental to the success of the company. Inferiorshareholders can garner significant long-term benefits by the founder being bonded to the firm and incentivised to develop the firm's vision over the long-run. The way in which the company differentiates itself from the rest of the market and the founder's self-perceived ability to outperform the market in the long-term has been described as the founder's 'idiosyncratic vision'. ${ }^{107}$ A juxtaposition can be drawn between the decade-and-a-half of financial problems that beset Apple, a OSOV-firm, after one of the founders, Steve Jobs, left in 1985 following a dispute with the board, ${ }^{108}$ and the continued incumbency of Mark Zuckerberg at Facebook, a dual-class firm, in the face of opposition from the board and shareholders to the acquisition of Instagram, Inc. for \$1bn in 2012 (which, by 2018 , was valued at $\$ 35 \mathrm{bn}) .{ }^{109}$

Of course, if the relevant founder is not talented, given the wide scope granted to him/her through dual-class stock to run the business, the bonding effect could, instead, be viewed as a detriment. ${ }^{110}$ However, with dual-class stock, the faith that the public investors possess in the relevant founder is critical. It is less likely that a dual-class IPO of a firm will be successful if potential investors do not have faith in the talents and ability of the superior-shareholders. It is acknowledged that, in certain cases, investors may face a 'Hobson's Choice', ${ }^{111}$ where, in a competitive market

\footnotetext{
${ }^{106}$ The attachment of named figures to businesses is particularly felicitous in certain jurisdictions, such as Italy (A. Santoro et al "Deviations from the "one share - one vote" principle in Italy: recent developments - multiple voting rights shares and loyalty shares” (2015) 5 Bocconi Legal Papers 141, at 164), and India ("Ratan Tata's Legacy” The Economist (1 December 2012) < https://www.economist.com/leaders/2012/12/01/ratan-tatas-legacy $>$ ).

${ }^{107}$ Goshen and Hamdani (2016) (note 70 above, at p. 577).

${ }^{108}$ M. Weinberger, 'This is why Steve Jobs got fired from Apple - and how he came back to save the company' Business Insider (31 July 2017) < https://www.businessinsider.com/steve-jobs-apple-fired-returned-2017-7?r=US\&IR=T>

${ }^{109}$ CFA Institute, 'Dual-Class Shares: The Good, The Bad and The Ugly (August 2018), at 8.

${ }^{110}$ See note 152 below, and accompanying text.

${ }^{111}$ ISS M\&A Deal Note (North America), "The Tragedy of the Dual Class Commons" (13 February 2012) 1, at 1 $<$ http://online.wsj.com/public/resources/documents/facebook0214.pdf $>$
} 
between fund managers, investors will be reticent to miss-out on an investment in a company with potentially excellent growth prospects, ${ }^{112}$ especially in a generally weak or small market for IPOs. ${ }^{113}$ However, it is difficult to foresee that an IPO of a tech-firm will proceed with dual-class structure if the investors do not have at least a modicum of conviction in the abilities of the founder. For example, although the decision by The We Company (WeWork) to abandon its IPO on short-notice will have been based partly upon misgivings about the company's business plan and finances, an underlying distrust of the founder's abilities was exposed when, soon after, it was announced that the founder would resign as CEO and potentially relinquish his superior-shares. ${ }^{114}$ Similarly, it is unlikely that Uber would have countenanced a listing prior to the removal of Travis Kalanick, whose behaviour had been very publicly denounced, as CEO, and unification of the dual-class structure to OSOV. ${ }^{115}$ Although dual-class shares in the UK previously died-a-death in the last millennium partly as a result of institutional investor aversion to the structure, ${ }^{116}$ the UK boards adopting the structure at the time were doing so primarily to protect themselves from a burgeoning hostile takeover market and were mainly industrial and retail companies with easily observable long-term growth-prospects, not redolent of contemporary, high-growth tech-firms which, as discussed, can particularly benefit from the adoption of dual-class stock. Today, notwithstanding the regular derision levelled at dual-class firms by institutional investors in the US, ${ }^{117}$ evidence is mixed as to whether institutional investors

${ }^{112}$ T. Wen, "You Can’t Sell Your Firm and Own It Too: Disallowing Dual-Class Stock Companies from Listing on the Securities Exchanges" (2014) 162 U. Pa. L. R. 1495, at 1505; A. Winden, "Sunrise, Sunset: An Empirical and Theoretical Assessment of Dual-Class Stock Structures" (2018) 3 C.B.L.R. 852, at 899.

113 Anand, "Governance Complexities in Firms with Dual Class Shares" (2018) 3 Annal. Corp. Gov. 184.

${ }^{114}$ A. Edgecliffe-Johnson and E. Platt, "WeWork founder trades voting power to back SoftBank rescue" Financial Times (21 October 2019) < https://www.ft.com/content/b9312eee-f440-11e9-b018-3ef8794b17c6>

${ }^{115}$ M. Isaac, "Uber Sells Stake to SoftBank Valuing Ride-Hailing Giant at $\$ 48$ Billion” The New York Times (December 28, 2017) < https://www.nytimes.com/2017/12/28/technology/uber-softbank-stake.html>

${ }^{116}$ See note 44 above.

117 See e.g. Council of Institutional Investors (CII), "Dual-Class Stock" < https://www.cii.org/dualclass stock $>$; ProxyInsight, “An interview with W. Robert Main III, Head of Portfolio Company Engagement, Analysis and Voting at Vanguard" Proxy Monthly (July 2017), at 4; Calpers Investment Committee, "Dual Class/Non-Voting Shares Update" (April 2018), at 9; A. Mooney, "Big investors fight back over dual-class shares" Financial Times (24 November 2019) <https://www.ft.com/content/bc220535-5055-47ce-811d-fc4a56d32937> 
actually shun such firms. ${ }^{118}$ It is likely that if a tech-firm conducts an IPO with dual-class structure, the founder will be an individual that the market views as fundamental to the success of the business, and public investors will derive value from a founder with an idiosyncratic vision being bonded to the firm.

A counter-argument, though, is that even if institutional investors evade those IPOs where the relevant business of the company and the qualities of the founder do not justify dual-class structure, permitting dual-class firms on the premium-tier could give them an implicit regulatory seal of approval that could attract unsuspecting retail investors. However, retail investors constitute a nominal presence in the UK public equity markets, ${ }^{119}$ and, as such, an IPO will not proceed, as was the case with WeWork in the US, without institutional investor support. Index trackers that are required to invest in the constituents of specific indices (which must be premium-listed to be included in the FTSE UK-series) will also not be prejudiced, since they will only be compelled to invest in a firm after it has become a member of the relevant index, which can only occur after the IPO has completed, which, in turn, is contingent upon substantive non-index-tracker institutional investor support.

\section{WHY PROHIBIT DUAL-CLASS STOCK FROM THE PREMIUM-TIER?}

Above, it has been outlined that dual-class stock could encourage founders of UK tech-firms to list their companies on the LSE, and, having listed, could present substantive benefits to tech-firms, and, therefore, long-term shareholder (including public shareholder) value. One may therefore ponder why

\footnotetext{
${ }^{118}$ Finding that institutional investor ownership in dual-class firms was the same or greater than such ownership in OSOV-

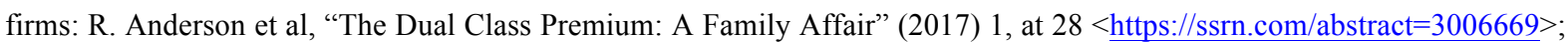
Smart et al, "What's in a vote? The short- and long-run impact of dual-class equity on IPO firm values" (2008) 45 J. Account. Econ. 94, at 99. Finding slightly less institutional ownership in dual-class firms: K. Li et al, "Do Voting Rights Affect Institutional Investment Decisions? Evidence from Dual-Class Firms” (2008) 37 Financial Management 713, at 720; J. Kim et al, "Multi-Class Shares Around the World: The Role of Institutional Investors" (November 2018) Unpublished 1, at 19 .

${ }^{119}$ As of 31 December 2018, individual investors only owned 13.5 per cent. of UK quoted shares (ONS, "Ownership of UK quoted shares: 2018”)
} 
the FCA has prohibited such structures from the premium-tier? The answer lies in the enigmatic nature of dual-class stock - for all the benefits that they present, they can also epitomise risks to public shareholders. In this section, the detriments to public shareholders of dual-class structure will be outlined, but also challenged in the context of high-growth tech-firms, and the UK's regulatory and market environment. It will be argued that the fear held by institutional investors of UK dual-class firms may be unwarranted.

Since OSOV-controlling shareholder firms are not prohibited from the premium-tier, the mere fact that a founder holds the balance of power within the firm and that the management team is insulated from removal by the public shareholders, can not be the sole motivation for the dual-class stock prohibition. The answer lies in the distortion to the controlling shareholder dynamic caused by the disconnect between the ownership of voting and cash-flow rights. As the founder progressively reduces its cash-flow rights, any exercise by the founder of its control over the company that harms the financial health of the company will have less of an impact on the founder's wealth. In essence, the founder will fail to fully feel the consequences of its actions. ${ }^{120}$ The concern is that the founder will be incentivised to take actions that benefit the founder personally to the detriment of the interests of the company and the other shareholders. Such personal benefits are known as 'private benefits of control'. The extraction of private benefits can, as follows, manifest itself in a number of actions that could be detrimental to inferior-shareholders.

An obvious potential mischief is where the founder 'tunnels' assets and profits out of the firm for its own benefit. ${ }^{121}$ Such 'tunnelling' could occur through sweetheart deals, the simple withdrawing of corporate funds, ${ }^{122}$ or the appropriation of corporate opportunities. ${ }^{123}$ In addition, a founder could cause the company to enter into transactions with other entities, in which the founder

\footnotetext{
${ }^{120}$ F. Easterbrook and D. Fischel, "Voting in Corporate Law" (1983) 26 J. Law Econ. 395, at 409; H. Hu and B. Black, "The New Vote Buying: Empty Voting and Hidden (Morphable) Ownership” (2006) 79 S. Cal. L. Rev. 811, at 851; HKEX Concept Paper (2017) (note 17 above, at p. 18).

${ }^{121}$ S. Johnson et al, "Tunnelling" (2000) NBER Working Paper 7523 1, at 2. The authors attribute the genesis of the term to the expropriation of minority shareholders in the Czech Republic ("as in removing assets through an underground tunnel").

${ }^{122}$ Ashton (1994) (note 97 above, at p. 916).

${ }^{123}$ D. Solomon, “The Importance of Inferior Voting Rights in Dual-Class Firms” (2017) 1, at pp. 15 and 16).
} 
owns a greater proportion of the cash-flow rights than in the relevant company, on non-arm's length terms unfavourable to the relevant company. Since cash-flow is being diverted to, essentially, the founder, inferior-shareholders in the first entity are being expropriated. ${ }^{124}$ Aspects of English law and regulation should, though, curtail tunnelling of this nature. Out-and-out stealing would clearly be fraudulent, ${ }^{125}$ and the laws in relation thereto are bolstered by the UK's strong accounting regime and financial press, both of which should aid the discovery of blatantly fraudulent acts. Short of outright theft, Chapter 11 of the Listing Rules introduces related-party transaction regulations for premiumlisted companies. ${ }^{126}$ If a founder holding control as a superior-shareholder ${ }^{127}$ were to cause a dualclass firm to enter into a transaction with the founder or one of its associates (including another company controlled by that founder), unless the transaction is in the ordinary course of business or below the size-threshold that triggers the regulations, prior to entering into the transaction, the company's sponsor ${ }^{128}$ must confirm that it is fair and reasonable to all shareholders. If the transaction exceeds a further threshold, it must be pre-approved by a vote of the shareholders independent of the related-party (the founder, as the superior-shareholder, in this case). ${ }^{129}$ Furthermore, in the presence of a controlling shareholder, ${ }^{130}$ a premium-listed company must enter into a 'relationship agreement'

${ }^{124}$ See note 121 above, at p. 7; M. Bertrand et al, "Ferreting Out Tunneling: An Application to Indian Business Groups" (2002) 117 Q. J. Econ. 121, at 139.

${ }^{125}$ Fraud Act 2006; also see Theft Act 1968, ss. 17 and 19.

${ }^{126}$ Disclosure requirements also apply to related-party transactions under the International Accounting Standards (IAS 24) and, if material, under the FCA's Disclosure Rules and Transparency Rules sourcebook (DTR) (DTR 7.3) and LR 21.8.17BR. For companies incorporated in England and Wales, board approval requirements (excluding the founder and associates) would also be required for material related-party transactions (DTR 7.3.8R).

${ }^{127}$ A founder holding a majority of votes would be a related-party as a 'substantial shareholder', being, broadly, a shareholder holding $10 \%$ or more of the votes (LR 11.1.4R).

${ }^{128}$ Premium-listed companies must appoint a person, who must be an authorised person (see: FSMA 2000, s.31) or member of a designated professional body (LR 8.6), approved by the FCA to provide sponsor services (LR 8.2) to advise the issuer on its listing obligations, and to give assurances to the FCA that the issuer's responsibilities thereunder are being met.

${ }^{129}$ In relation to the thresholds pertaining to related-party transactions, see LRs 11.1.5R and 11.1.7, and LR 10 Annex 1.

${ }^{130}$ A founder with majority-control would be a 'controlling shareholder' for these purposes, being, broadly, a shareholder holding $30 \%$ or more of the votes (LR App 1.1). 
with the controlling shareholder, ${ }^{131}$ under which, inter alia, the controlling shareholder must agree to conduct all transactions with the company under arm's length and normal commercial terms. ${ }^{132}$ If that relationship agreement is breached by, for example, a related-party transaction being entered into between the founder and the company on non-arm's length terms, the thresholds for related-party transactions are disapplied, ${ }^{133}$ and the relevant transaction would require independent shareholder preapproval no matter its size or whether or not the transaction is in the ordinary course of business. Related-party transaction regulations of this nature should at least limit the most egregious forms of tunnelling.

The US, where the largest dual-class firms reside, also employs related-party transaction protections, ${ }^{134}$ and it is not a coincidence that truly insidious examples of tunnelling are rare. ${ }^{135} \mathrm{~A}$ note of caution, though, is that in the OSOV-sphere, related-party transaction controversies have still occurred at controlling shareholder companies in the UK. ${ }^{136}$ Those controversies arose from the related-party regulations not covering the relevant transactions, the nature of the transactions creating obfuscation as to whether the relevant thresholds had been satisfied, or the narrow definition of 'associate' under the Listing Rules not covering the family member of the controlling shareholder transacting with the company. ${ }^{137}$ As a result, transactions were unintentionally or, perhaps even intentionally, not treated as related-party transactions. Therefore, as suggested by Reddy (2018), it may be conducive to tighten-up related-party regulations for controlling shareholder firms (including

\footnotetext{
${ }^{131}$ LRs 6.5.4R and 9.2.2ADR(1).

${ }^{132}$ LR 6.5.4R.

${ }^{133}$ LR 11.1.1AR.

${ }^{134}$ In Delaware, upon a challenge, the Courts may require the company to prove that a conflicted transaction was made on the basis of fair price and process, and fair to the public shareholders (Weinberger v UOP, Inc., 457 A.2d 701, 703 (Del. 1983)).

135 The only examples of extreme, criminal, tunnelling at US dual-class firms were at Adelphia Communications Corporation (S. Gilson and B. Villalonga, “Adelphia Communications Corp.’s Bankruptcy” (2010) Harvard Business School Case 208-071 1, at 6) and Hollinger International (Cipollone (2012) (note 23 above, at p. 75).

${ }^{136}$ For example, at the companies Eurasian Natural Resources Corporation plc (ENRC), Bumi plc, Exillion Energy plc, Sports Direct International plc (Sports Direct) and Ferrexpo plc (note 37 above, at p. 757 et seq).

${ }^{137}$ Ibid., at pp. 751 and 760, in relation to Sports Direct and ENRC respectively.
} 
dual-class firms if they were permitted on the premium-tier) by broadening the definition of associate as it pertains to controlling shareholder family-members, and by requiring that all related-party transactions, regardless of size, be confirmed by the firm's sponsor as fair and reasonable to all shareholders. ${ }^{138}$

The extraction of private benefits could, though, occur more subtly in a manner that does not trigger related-party transaction regulations. For example, a founder may cause a dual-class firm to acquire assets or pursue projects that generate personal benefits for the founder, but are not shareholder wealth-maximising. Those benefits may not just be financial in nature. Non-pecuniary benefits could also subsist, such that, in the context of tech-firms, the project is detrimental to shareholder-wealth, but represents a 'pet-project' for the founder or generates significant publicity and fame for the founder owing to its ambition or innovation. ${ }^{139}$ Similarly, the founder may retain assets or persist with projects rather than selling or abandoning them, due to the substantial private benefits that the founder can extract. Inefficient decision-making of this kind has classically been cited by advocates of OSOV, ${ }^{140}$ and could even theoretically lead to dual-class firms becoming inefficiently large and evolving into unwieldy conglomerates. ${ }^{141}$ It is therefore accepted that subtle private benefit extraction leading to inefficient decision-making could still prevail in UK dual-class firms.

In the context of tech-firms, though, two aspects bear consideration. Firstly, the types of techfirms that are likely to benefit from dual-class stock are growth-phase companies that need to invest heavily in R\&D. With debt-funding scarce, ${ }^{142}$ such companies may, post-IPO, have to make regular excursions to the equity-markets for further financing. If the founder has, in the interim, developed a reputation for extracting substantial private benefits (assuming that those private benefits have not been obscured, and have had a detrimental effect on firm-wealth), the cost of capital will have

\footnotetext{
${ }^{138}$ Ibid., at p. 760 .

${ }^{139}$ A. Dyck and L. Zingales, "Private Benefits of Control: An International Comparison" (2004) 59 J. Financ. 537, at 540; Gilson (2006) (note 85, at p. 1664).

${ }^{140}$ Easterbrook and Fischel (1983) (note 120 above, at p. 409).

${ }^{141}$ L. Bebchuk et al, "Stock Pyramids, Cross-Ownership, and Dual Class Equity: The Mechanisms and Agency Costs of Separating Control from Cash-Flow Rights” in R. Morck (ed.), Concentrated Corporate Ownership (Chicago 2000), 303.

142 note 20 above, and accompanying text.
} 
increased, making such equity-financing much more expensive. ${ }^{143}$ Therefore, although the management team's insulation from the public markets can engender a long-term approach to the business, management can not completely disregard short-term consequences. Of course, a wholesale relaxation of the premium-tier prohibition of dual-class firms could open-up the market to non-highgrowth firms, in relation to which the benefits of dual-class stock outlined in this article are possibly less relevant, and, therefore, could be overshadowed by the detriments. Although outside the scope of this article, consideration should therefore be given to restricting dual-class stock to certain types of companies, or requiring the issuer to justify the need for, and benefits of, dual-class stock on a firmspecific basis. The Hong Kong stock exchange (HKEX) requires dual-class firms seeking admission to evidence their 'innovative' credentials, ${ }^{144}$ and the exchanges of Singapore (SGX) ${ }^{145}$ and Tokyo (TSE) ${ }^{146}$ require justifications based upon the qualities of the firms that make dual-class stock beneficial. The Shanghai stock exchange (SSE) is more granular and only permits dual-class listings on a separate board for science or technology companies (the STI Board). ${ }^{147}$ The FCA should consider whether some form of restriction would be germane, although, it is accepted that, in such a case, the existing expertise and capacity of the FCA in making such determinations on an on-going basis may need to be enriched. An alternative approach would be for the FCA to play an intrinsic role in ensuring that the proposed issuer publicly discloses sufficient information prior to IPO which would enable the market to make a fully-informed decision as to whether the rationale for adoption of dual-class structure is justified based upon the nature of the company's business, the company's growth-profile, and the importance of the superior-shareholders to the success of the company.

Second, a founder will not have disposed of equity in the dual-class firm entirely. To the extent that the founder possesses at least a proportion of equity, it will feel some pain from taking

${ }^{143}$ In relation to controlling shareholders generally: A. Shleifer and R. Vishny, “A Survey of Corporate Governance” (1997) 52 J. Financ. 737, at 749; R. La Porta et al, “Legal Determinants of External Finance” (1997) 52 J. Financ. 1131, at 1149.

${ }^{144}$ HKEX Guidance Letter HKEX-GL93-18, "Suitability for Listing with a WVR Structure” (April 2018), at para. 4.2.

${ }^{145}$ SGX, "Consultation Paper: Proposed Listing Framework for Dual Class Share Structures” (28 March 2018), at 2.

${ }^{146}$ TSE, "New Listing Guidebook: $1^{\text {st }}$ and $2^{\text {nd }}$ sections" (2018), at 142.

${ }^{147} \mathrm{~K}$. Ho, "Examining the viability to allow dual-class share structure companies to list in the financial market of the People's Republic of China: Lessons and experiences from Hong Kong” (2019) 1, at 26 $<\underline{\text { https://papers.ssrn.com/sol3/papers.cfm?abstract } \mathrm{id}=3408873 \& \text { download=yes }>}$ 
actions that are detrimental to firm-wealth. However, that 'pain' palliates at a sharply increasing rate as the controller's cash-flow rights decrease, ${ }^{148}$ and it appears, in the US context, that controllers of dual-class firms reduce their equity holdings over time. Bebchuk and Kastiel $(2017)^{149}$ found that for the ten largest US dual-class firms (by market capitalisation), at IPO, the controllers of those firms held, on average, 30 per cent. of the equity - not an insubstantial level of cash-flow rights. However, post-IPO, as of 2015, the average cash-flow rights held by those controllers, who had retained at least effective control of their firms, had fallen to 11.6 per cent. Therefore, consideration should be given as to whether controllers of dual-class firms should, as a quid pro quo to enjoying enhanced voting rights, be required to hold a minimum level of equity. HKEX, for example, requires superiorshareholders to hold at least 10 per cent. of the equity in the company. ${ }^{150}$ Determining the minimum threshold that adequately constrains controllers can be an ethereal task, and may vary on a firm-byfirm or, even, controller-by-controller basis. Furthermore, the level needs to be balanced so that it acts as a constraint on the most serious forms of abuse, but not so great that it undermines the ability of the controller to take risks and a long-term approach to the business. Determining the relevant threshold is an undertaking for future study, but it is hereby contended that any such threshold should embrace a degree of flexibility on a case-by-case basis. ${ }^{151}$

Management insulation has been described as a positive trait of dual-class firms, but, it could also be described negatively as 'management entrenchment'. As long as management satisfies the aspirations of the controller, possibly even in priority to the interests of the shareholders as a whole, they will not have any fear of losing their employment. The inability of the public shareholders to remove directors is an inherent risk for them, since without the deterrent of removal, managers may not perform efficiently or diligently, or, worse, act in a self-serving manner; especially exacerbated where the controller only holds a small level of cash-flow rights, reducing the equity-constraining

\footnotetext{
${ }^{148}$ See note 141 above, at p. 295 ; note 68 above, at p. 1473.

${ }^{149}$ See note 54 above, at p. 608 .

${ }^{150}$ HK Listing Rules, Rule 8A.12.

${ }^{151}$ HKEX, for example, recognises that the $10 \%$ threshold may be lowered for firms with market capitalisation of HK\$80 billion or more.
} 
effect. ${ }^{152}$ Although enabling long-termism and risk-taking have been discussed as benefits accruing to dual-class firms in the tech-sphere, if the founder is untalented, pretensions toward long-termism could simply be masking a malfunctioning strategy that is harmful to shareholder-wealth in the shortand long-term, or risk-taking could be purely speculative and no more calculated than the worst Vegas gambler. With respect to high-growth tech-firms, though, as discussed above, it is likely that the public shareholders have invested in the relevant firm at IPO based upon their confidence in the abilities of the founder to lead the management of the company. Empirical evidence from other jurisdictions suggests that, for high-growth firms, the market recognises that the benefits accruing to the structure outweigh the detriments, since firm valuations for high-growth dual-class firms are greater than for matched OSOV-firms. ${ }^{153}$ If investors had considerable concerns over the future performance of the management team, firm valuations would likely be lower. Of course, outside investors are not infallible in judging the abilities of the founder, but their desire to invest at a premium would be based upon evidence of past-performance, and firm valuation studies are usually conducted over robust periods of time, such that if the founder turned-out to be untalented post-IPO, it is unlikely that the valuation premia identified would endure. This does, though, highlight the potential importance of restricting dual-class structure to specific types of firms, as referenced above. $^{154}$

A critical issue is that the impact of management entrenchment on shareholder-value could transmute over time. Studies have suggested that dual-class firm valuations (and possibly operating performances) decline with age of firm ${ }^{155}$ or time since $\mathrm{IPO}^{156}$ at a greater rate than OSOV-firms to

\footnotetext{
${ }^{152}$ See note 120 above.

${ }^{153}$ B. Jordan et al, "Growth opportunities, short-term market pressure, and dual-class share structure" (2016) 41 Journal of Corporate Finance 304; Y. Bozec and C. Laurin, "Large Shareholder Entrenchment and Performance: Empirical Evidence from Canada" (2008) 35 J. Bus. Finance Account. 25.

${ }^{154}$ See notes 144-147 above, and accompanying text.

${ }^{155}$ Kim and R. Michaely, "Sticking Around Too Long? Dynamics of the Benefits of Dual-Class Structures" (2018) 1 $<\underline{\text { https://ssrn.com/abstract }=3145209>}$

${ }^{156}$ M. Cremers et al, "The Life-Cycle of Dual Class Firms: From IPO to Sunset” (2018) ECGI Working Paper No. 550/2018 1.
} 
the extent that they are eventually performing worse than matched OSOV-firms. ${ }^{157}$ Some have suggested that this characteristic warrants the mandatory imposition of mechanisms that cause dualclass structure to automatically convert to OSOV upon the expiry of a period of time since IPO ('time-dependent sunset clauses'). ${ }^{158}$ On the face of it, in the context of high-growth tech-firms, the rationale is sound - during the growth-phase of the firm, dual-class structure enables the founder to invest in R\&D and long product-cycles that are beneficial in the long-term but the benefits of which are perhaps unobservable to the public markets in the short-term; however, once the company has matured with completed product-cycles and a stable business plan, it becomes more difficult to identify the benefits of the structure to public shareholders, and the detriments will begin to dominate. However, rather than the age of the firm itself being the reason for a decline in performance, time is merely a proxy for events that are more likely to occur as time passes. ${ }^{159}$ A key event would be where the original founder, in which the investors had placed their faith, transfers control to a third-party. Even if that transferee were a family-member of the founder, numerous studies have shown that controlling shareholder firms perform worse where control is in the hands of heirs as opposed to the original founder. ${ }^{160}$ Again, although a detailed consideration of the restrictions that could be formulated in parallel with a relaxation of the premium-tier prohibition of dual-class stock is ceded to further study, briefly, a relevant consideration would be to ensure that enhanced voting rights are

${ }^{157}$ However, the results may also be explained by high-growth firms forming a disproportionate percentage of dual-class IPOs, and therefore declining at a greater extent than lower-growth firms as they attain maturity.

158 CII Letter to E. King, Chief Regulatory Officer, International Exchange Inc. (24 October 2018) $<$ https://www.cii.org/files/issues and advocacy/correspondence/2018/20181024 NYSE Petition on Multiclass Sunsets FINAL.pdf>; also, see: Bebchuk and Kastiel (2017) (note 54 above, at p. 631); note 155 above, at p. 29; note 156 above, at p. 41.

${ }^{159}$ Johnson et al (2018) (note 89 above, at p. 5)

${ }^{160}$ See e.g. Anderson et al, "Founding-Family Ownership and Firm Performance; Evidence from the S\&P 500" (2003) 58 J. Financ. 1301, at 1321; R. Morck et al "Inherited Wealth, Corporate Control, and Economic Growth: The Canadian Disease" in R. Morck (2000) (note 141 above, at p. 319); M. Bennedsen et al, "Inside the Family Firm: The Role of Families in Succession Decisions and Performance" (2007) 122 Q.J. Econ. 647, at 669; B. Villalonga and R. Amit, "How Do Family Ownership, Control and Management Affect Firm Value?" (2006) 80 J. Fin. Econ. 385, at 403; M. van Essen et al, "How does Family Control Influence Firm Strategy and Performance? A Meta-Analysis of US Publicly Listed Firms” (2015) 23 Corp. Gov. 3, at 18. 
premised on the original superior-shareholders continuing to hold the superior-shares (or at least control of the company), with those shares converting into inferior-shares upon a relevant transfer. HKEX, ${ }^{161} \mathrm{SGX}^{162}{ }^{162} \mathrm{TSE}^{163}$ and $\mathrm{SSE}^{164}$ all include similar requirements for dual-class firms. Even with such a restriction, other events could also occur over time that cause declining performance, such as where growth-prospects decline, the original founder's skills and abilities wane, or the founder sellsdown further equity incentivising greater private benefit extraction. A requirement for the founder to hold a threshold level of equity as referred to above ${ }^{165}$ could assuage these issues by ensuring that the founder thinks twice about extracting pernicious private benefits, or even about continuing in day-today management when shareholder-wealth would be better served by relinquishing management to fresh leadership. By ensuring that the founder owns at least a non-negligible level of 'skin-in-thegame', it will also be less likely to take purely speculative risks mitigating against the actions of a poor gambler as mentioned above. On the other hand, time-dependent sunset clauses are cruder mechanisms, being arbitrary in nature - it is impossible to deduce with accuracy at the time of IPO exactly when the benefits of dual-class structure will begin to be overshadowed by the detriments. ${ }^{166}$

Another criticism of dual-class firms that could be considered to be an egregious form of private benefit extraction relates to the generation of 'control premia' upon a takeover of the firm. Control premia emerge in two respects: (i) an acquiror solely acquires the superior-shares, thereby acquiring control without the inferior-shareholders receiving any consideration; or (ii) the acquiror acquires all the shares in the company but pays a higher price for the superior-shares as compared to the inferior-shares.

\footnotetext{
${ }^{161}$ See note 150 above, Rule 8 A.18.

${ }^{162}$ SGX Mainboard Rules, Rule 210(10).

${ }^{163}$ See note 146 , at p. 145.

${ }^{164}$ STI Board Rules, article 4.5.10.

${ }^{165}$ See notes 150-151 above, and accompanying text.

${ }^{166}$ J. Fisch and S. Solomon, “The Problems of Sunsets” (2019) U. of Penn., Law School Research Paper No. 19-04 1, at 17;

B. Sharfman, "The Undesirability of Mandatory Time-Based Sunsets in Dual Class Share Structures: A Reply to Bebchuk and Kastiel” (2019) 93 S.C.L.J. 1; M. Moore, "Designing Dual Class Sunsets: The Case for a Transfer-Centered Approach" (2019), at $27<$ https://papers.ssrn.com/sol3/papers.cfm?abstract id=3478572>
} 
In the UK, though, the ability to extract control premia is significantly mitigated by mandatory bid and comparable treatment requirements. In relation to public companies registered and traded (or with central management and control) in the UK, the Isle of Man or the Channel Islands, and certain categories of EEA companies, ${ }^{167}$ with securities traded on, inter alia, the Main Market, mandatory offer rules apply where any persons acting together in concert acquire shares carrying 30 per cent. or more of the voting rights in that company; such persons must make an offer for all the remaining shares of each class in the company, at not less than the highest price offered for a particular class of shares in the 12-month period prior to the offer. ${ }^{168}$ Therefore, with regards to the first scenario, a potential acquiror will not be able to acquire control of the company merely by making an offer for the superior-shares; an offer for all the shares in the company, no matter the class or voting rights attached, must be made. With regards to the second scenario, with multiple classes of shares, a bidder must pay to each class of shareholder at least the highest price paid by the bidder for shares of that class during the 12 months prior to the announcement of the offer, ${ }^{169}$ and offers made for each class of shares must be 'comparable'. ${ }^{170}$ 'Comparable' does not necessarily mean 'identical', and the Takeover Panel must be consulted, ${ }^{171}$ but, prima facie, the Takeover Panel will insist that the ratio of the offer-values be equal to "the average of the ratios of the middle-market quotations [for each class of shares] taken from the Daily Official List over the course of the six months preceding the commencement of the offer period' ${ }^{172}$ Accordingly, if superior-shares and inferior-shares were listed in the UK, investors would not be caught off-guard by any potential control premium, since it would be based upon prevailing market prices, and, in any case, it is unlikely that the difference in market price between superior-shares and inferior-shares would be large. ${ }^{173}$

\footnotetext{
${ }^{167}$ Takeover Code, Section A3.

${ }^{168}$ Ibid., at Rule 9.

${ }^{169}$ Ibid., at Rule 9.5.

${ }^{170}$ Ibid., at Rule 14.1.

${ }^{171}$ Ibid., at Rule 9.5 .

172 Ibid., at Notes to Rule 14.1.

${ }^{173}$ If inferior-shares and superior-shares were premium-listed, where a controller holds a majority of the voting rights, as a result of mandatory offer rules, a minority holding of superior-shares is unlikely to be of substantially greater value to a third party as compared to a minority interest in the inferior-shares (A. Stumpf and A. Cline, "Price Differentials Between Voting
} 
Of course, where a founder seeks to retain majority-control, in most cases, the superior-shares will not be listed. ${ }^{174}$ In the case of a UK mandatory bid, where the superior-shares are not listed, the Takeover Panel would not be able to apply the voting premium formula in assessing 'comparable' price, if, for instance, a bidder triggers the Takeover Code's mandatory offer requirements by acquiring unlisted superior-shares. However, in such circumstances, it is difficult to envisage that the Takeover Panel will not insist that the same price be paid for equal equity interests, requiring that the price paid per listed inferior-share be the same as the highest price paid per unlisted superior-share.

Although the Takeover Code will cease to apply to EEA firms after the UK leaves the EU, ${ }^{175}$ most EU-jurisdictions have also implemented mandatory offer rules. ${ }^{176}$ Control premia should therefore be irrelevant for the vast majority of premium-listed firms if dual-class stock were permitted. ${ }^{177}$ In fact, when takeovers of dual-class firms do occur (which would require the acquiescence of the controller), since the controller can negotiate directly with the potential acquiror and will not sell-out unless it is compensated for the loss of its private benefits, ${ }^{178}$ takeover prices will be higher than with OSOV dispersed-ownership firms. ${ }^{179}$ Pursuant to the mandatory offer rules, all shareholders can share in those higher takeover prices.

and Nonvoting Stock" Stout Advisory Services <https://www.stout.com/en/insights/article/price-differentials-betweenvoting-and-nonvoting-stock/> 4).

${ }^{174}$ With respect to the US: P. Gompers et al, "Extreme Governance: An Analysis of Dual-Class Firms in the United States" (2010) 23 Rev. Financial Stud. 1051, at 1056.

175 The Takeover Panel, Code Committee Response Statement RS2018/2, “The United Kingdom's Withdrawal from the European Union" (6 March 2019), at 10.

${ }^{176}$ Bonellierede, Bredin Prat, De Brauw, Hengeler Mueller, Slaughter and May and Uría Menéndez, “Guide to Public Takeovers in Europe" (June 2016).

${ }^{177}$ Out of 1161 Main Market-listed companies, 852 were registered in the UK, Channel Islands or Isle of Man, and 107 were registered in another EEA country (LSE, “Company List” (31

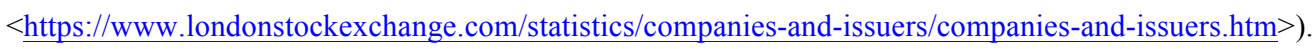

${ }^{178}$ M. Barclay and C. Holderness, "Private benefits from control of public corporations" (1989) 25 J. Financ. Econ. 371 , at 380; Gilson (2006) (note 85 above, at p. 1672).

${ }^{179}$ Empirically, see Bauguess et al (2012) (note 100 above, at p. 1249); Smart and Zutter (2003) (note 82 above, at p. 102). 
Finally, high executive remuneration has also been identified as a potentially sinister form of private benefit extraction. ${ }^{180}$ Theoretically, a founder involved in management could cause the company to pay himself/herself substantially above-market levels of executive pay, and, with dualclass stock, the founder may be incentivised to do so through a combination of suffering a smaller downside as a result of its smaller equity-holding, and receiving lower regular equity income. However, in jurisdictions which mandate high levels of executive pay disclosure, outrageously high levels of pay would likely attract significant shareholder, public and media opprobrium, which, notwithstanding isolated instances of excessive compensation, should, when purveying the overall picture, act as a moderating mechanism in this regard. ${ }^{181}$ In the UK, quoted companies must prepare a directors' remuneration report which must disclose detailed information relating to directors' remuneration. ${ }^{182}$ The contents must be publicly disclosed on the company's website. ${ }^{183}$ Furthermore, in the OSOV-sphere, shareholders have an advisory vote on the implementation of directors' remuneration, and a binding vote on directors' remuneration policy. ${ }^{184}$ With dual-class stock, the controller will be able to carry the vote. However, with OSOV-firms, even the loss of non-binding advisory votes can cause companies to re-assess their pay policies. ${ }^{185}$ A similar course could be followed with dual-class stock firms, although the Listing Rules would need to be amended to provide that such companies disclose the results of voting by shareholders independent of the superiorshareholders if the superior-shareholders possess voting-control. Even if one were sceptical as to the sagacity of 'say-on-pay' votes and disclosure requirements, in the US (which also enjoys high levels

\footnotetext{
${ }^{180}$ B. Amoako-Adu et al, "Dual class discount, and the channels of extraction of private benefits" (2013) 16 Adv. Financ. Econ. 165, at 195 .

181 'Outrage costs and constraints' as coined by L. Bebchuk and J. Fried (eds.), Pay Without Performance, (Cambridge 2004), 5 .

${ }^{182}$ CA 2006, ss. 420 and 421.

${ }^{183}$ CA 2006, s. 430.

${ }^{184}$ CA 2006, ss. 439 and 439A.

185 e.g., in 2016, the remuneration committee of BP plc used its discretion to reduce performance-related pay to which the CEO was otherwise entitled to avoid 'formulaic outcomes', after the company had lost the advisory vote on the implementation of the remuneration policy in the previous financial year; and at Persimmon plc, in 2017 the chair, and in 2018 the CEO, resigned after shareholder and public outrage toward the CEO’s $£ 110$ million pay package.
} 
of executive pay disclosure $\left.{ }^{186}\right)$, in practice, executive pay at dual-class firms is not excessive compared to OSOV-firms, and, in any case, is very much a drop-in-the-ocean compared to market capitalisation. ${ }^{187}$ As an extreme example, at Google, the founders famously annually only pay themselves $\$ 1$ in salary. ${ }^{188}$ Although a dual-class firm controller has the legal power to pay itself any sum by way of executive compensation, it is unlikely that high executive remuneration will be a significant issue causing public shareholders harm if dual-class firms were permitted on the premiumtier, and, in any case, the regulators could continue to monitor on an on-going basis whether further regulatory intervention is required.

In summary, although, from a theoretical perspective, dual-class structure can present a variety of potential detriments to inferior-shareholders, the most egregious possible acts of controllers are restricted by existing qualities of the UK's market and regulatory environment. Even in relation to more subtle forms of private benefit extraction, with respect to high-growth tech-companies, such extraction is not excessive in practice, and can, with measured regulatory revisions, be limited. For the UK tech-industry, it is unlikely that the potential detriments to public shareholders of dual-class structure will outweigh the benefits.

\section{CONCLUSION}

Whereas the US and China have surged ahead in the era of Big Tech, with numerous tech-company behemoths listed on their (and other) exchanges, the UK has lagged behind. Despite policy initiatives by the UK regulators and UK Government, currently, founders of tech-firms may be deterred from

\footnotetext{
${ }^{186}$ Dodd-Frank Wall Street Reform and Consumer Protection Act (Pub. L. 111-203 (2010)), Subtitle E of Title IX.

187 e.g., between 2001 and 2007, the average CEO compensation for dual-class firms was $\$ 5.2 \mathrm{~m}$ compared to $\$ 4.7 \mathrm{~m}$ for matched OSOV-firms (Amoako-Adu et al (2013) (note 180 above, at p. 183). Although, Masulis et al "Agency Problems at Dual-Class Companies" (2009) 64 The Journal of Finance 1697, at 1707 found more striking results showing that average US CEO total compensation between 1995 and 2003 increased by $\$ 1.054 \mathrm{~m}$ as the ratio of insiders' voting rights to cashflow rights rose by one standard deviation, this should be considered in the context of average market capitalisation - in 2017 , the average market capitalisation of a US-listed company was $\$ 7.3 \mathrm{bn}$, and even in 2001 , the average was above $\$ 3 \mathrm{bn}$ (Ernst \& Young, "Looking behind the declining number of public companies" (May 2017), at 3 and 2).

${ }^{188}$ Proxy Statement Schedule 14(A) of Alphabet Inc. (30 April 2019), at 43.
} 
listing on the premium-tier of the LSE's Main Market due to its adherence to OSOV. Either they will need to cede control upon flotation of the company, or they can retain control upon IPO but suffer from lower levels of equity fund-raising for growth, and less personal wealth diversification.

Dual-class stock can provide an avenue for UK tech-firm listings, enabling founders to crystallise wealth and raise substantial equity-capital for growth, while retaining control. Judging by the plethora of recent US tech-firm dual-class IPOs, the countenance of dual-class stock on the premium-tier could attract further tech-company flotations. Once listed, the insulation that dual-class structure provides against the short-term proclivities of public shareholders and the market for corporate control supports the taking of a long-term approach to the business of the company, allowing the founder to invest in $\mathrm{R} \& \mathrm{D}$, long product-cycles and innovative ideas which can be profitable in the long-term, but not easily observable in the short-term, and continue to pursue his/her idiosyncratic vision. Such a founder can also take the risks essential to the success of companies operating in an innovative sector. To the extent that the public shareholders value the abilities of the founder, they can benefit from the founder being bonded to the firm for the long-term, which can also create consequential upside from the perspective of employee and other stakeholder relationships.

A suspicion of dual-class firms persists, though, as a result of the incentives on the controller to extract private benefits to the detriment of the interests of the company. As the cash-flow rights of the controller diminish, it will feel less 'pain' from taking actions that reduce share value. However, the existing UK market and UK regulatory environment substantially protects inferior-shareholders from the most egregious types of expropriation, and with respect to more subtle levels of expropriation, in practice, the concerns are overblown. Therefore, in the UK, the adoption of dualclass stock should not be feared, and greater consideration should be given to the benefits that could be secured by a relaxation of the premium-tier prohibition. Supplementary regulatory protocols can complete the picture and enhance the prospect that the benefits to public shareholders of dual-class firms will outweigh the detriments. Further study will formulate the detailed application of those concepts from a UK regulatory standpoint, but it is essential that any restrictions do not compromise the underlying benefits of the structure or undermine the ability of a founder to pursue its idiosyncratic vision. If that were the case, a relaxation of the premium-tier prohibition would be a fool's errand, and not attract the listings desired. 
The discussion should now evolve from whether or not dual-class shares should be permitted on the premium-tier, to how dual-class structure can be promoted on the premium-tier. The possible regulatory restrictions proposed herein could open the door to premium-tier dual-class firms, while maintaining the market's confidence in the premium-tier as a listing segment to which the highestlevels of corporate governance apply. Consequently, with those supplementary regulatory restrictions in place, those dual-class firms that do list on the premium-tier will see a lower cost of capital than would otherwise be the case, further attracting dual-class listings. Britain should be proud of its techsector, and in turbulent political and economic times, the entrepreneurship and innovation of the UK economy needs to be supported and nurtured. With dual-class shares permitted on the premium-tier of the LSE, a supercharged UK tech-industry can flourish, and, finally, the lesser-spotted British Google may appear on the horizon. 
APPENDIX

Table 1

\begin{tabular}{|c|c|c|c|c|}
\hline $\begin{array}{c}\text { UK Private } \\
\text { Company Target }\end{array}$ & Year of Acquisition & Acquiror & $\begin{array}{c}\text { Jurisdiction of } \\
\text { Acquiror }\end{array}$ & Acquisition Price \\
\hline DeepMind & 2014 & Google & USA & $\$ 650 \mathrm{~m}$ \\
\hline Vero Software & 2014 & Hexagon AB & Sweden & Unannounced \\
\hline Swiftkey & 2015 & Microsoft Corporation & USA & $\$ 250 \mathrm{~m}$ \\
\hline Onefinestay & 2016 & Accor & France & $£ 177 \mathrm{~m}$ \\
\hline Skyscanner & 2016 & $\begin{array}{c}\text { Ctrip.com } \\
\text { International, Ltd }\end{array}$ & China & $\$ 1.4 b$ \\
\hline $\begin{array}{l}\text { Magic Pony } \\
\text { Technology }\end{array}$ & 2016 & Twitter, Inc. & USA & $\$ 150 \mathrm{~m}$ \\
\hline Shazam & 2017 & Apple Inc. & USA & $\$ 400 \mathrm{~m}$ \\
\hline Momondo & 2017 & Booking Holdings & USA & $\$ 550 \mathrm{~m}$ \\
\hline Silverrail & 2017 & Expedia & USA & $\$ 148 \mathrm{~m}$ \\
\hline Vocalink & 2017 & Mastercard & USA & $\$ 700 \mathrm{~m}$ \\
\hline Nyx Games & 2018 & Scientific Games & USA & $\$ 626.5 \mathrm{~m}$ \\
\hline Callcredit & 2018 & TransUnion & USA & $\$ 1.4 b$ \\
\hline Ziylo & 2018 & Novo Nordisk & Denmark & $\$ 800 \mathrm{~m}$ \\
\hline Foundry & 2019 & Roper Technologies & USA & $\$ 544 \mathrm{~m}$ \\
\hline
\end{tabular}

Table 1 - Large (over $£ 100 \mathrm{~m}$ ) acquisitions of UK private technology companies since 2014

Sources: ONS, "Mergers and Acquisitions Involving UK Companies” (publications from Q3 2014 to Q2 2019); A. Sword, "6 of the biggest UK tech acquisitions by overseas giants" C.B.R. (18 July 2016) <https://www.cbronline.com/internet-ofthings/6-of-the-biggest-uk-tech-acquisitions-by-overseas-giants-4952343/>; A. Hern, "Is the global desire to buy British a bad thing for UK tech firms?" Guardian (16 December 2017) <https://www.theguardian.com/business/2017/dec/16/uk-techcompanies-bought-by-overseas-giants-apple-shazam> 
Table 2

\begin{tabular}{|c|c|c|c|c|}
\hline UK Listed Company & Year of Acquisition & Acquiror & $\begin{array}{c}\text { Jurisdiction of } \\
\text { Acquiror }\end{array}$ & Acquisition Price \\
\hline Invensys & 2014 & Schneider & France & $£ 3.4 \mathrm{bn}$ \\
\hline CSR & 2015 & Qualcomm & USA & $\$ 2.4 \mathrm{bn}$ \\
\hline $\begin{array}{c}\text { Advanced Computer } \\
\text { Software }\end{array}$ & 2015 & Vista & USA & $£ 725 \mathrm{~m}$ \\
\hline ARM & 2016 & SoftBank & Japan & $£ 24$ bn \\
\hline KBC & 2016 & Yokogawa & Japan & $\$ 180.3 \mathrm{~m}$ \\
\hline XChanging & 2016 & $\mathrm{CSC}$ & USA & $\$ 720 \mathrm{~m}$ \\
\hline PACE & 2016 & Arris & USA & $\$ 2.1 \mathrm{bn}$ \\
\hline Telecity & 2016 & Equinix & USA & \$3.8bn \\
\hline E2V Technologies & 2017 & $\begin{array}{c}\text { Teledyne } \\
\text { Technologies }\end{array}$ & USA & $£ 620 \mathrm{~m}$ \\
\hline Imagination & 2017 & Canyon Bridge & USA & $£ 550 \mathrm{~m}$ \\
\hline Worldpay & 2018 & Vantiv Inc & USA & $\$ 10.63 b n$ \\
\hline Sophos & 2019 & Thoma Bravo & USA & $\$ 3.9 \mathrm{bn}$ \\
\hline
\end{tabular}

Table 2 - Large (over $£ 100 \mathrm{~m}$ ) foreign buy-outs of UK-listed technology companies since 2014

Sources: ONS, "Mergers and Acquisitions Involving UK Companies” (publications from Q3 2014 to Q2 2019); J. Kollewe,

"UK cybersecurity firm Sophos agrees $£ 3.1 \mathrm{bn} \quad$ takeover" Guardian $(14$ October 2019)

< https://www.theguardian.com/business/2019/oct/14/uk-cybersecurity-sophos-takeover-thoma-bravo $>$ 